\title{
Kepribadian Orangtua Lintas Generasi di Indonesia: Tinjauan Big Five Theory
}

\author{
Nadila Apriola Susanto ${ }^{1}$ \& Ahmad Sulaiman ${ }^{2}$ \\ Fakultas Psikologi, Universitas Muhammadiyah Malang \\ E-mail: ${ }^{1}$ nadilaapriola@gmail.com, ${ }^{2}$ sulaiman_ahmad@umm.ac.id
}

\begin{abstract}
Individuals are part of and shaped by their community. In the past 50 years we have observed technological leaps that have changed the pattern of social relations and basic habits of society. Especially in Indonesia where industrialization and modernization occur together. This phenomena has produced a hypothesis that human's personality could be altered as well. However, there seems to be insufficient research evidence to test this assumption. This study aims to look at the personality of Indonesian parents of various generations. Personality test in the form of self-report instruments are administered to 80 subjects who are parents of four generations. The results show a significant difference in two aspects of personality which are emotional stability and openness to experience. This indicates the younger the generation, Indonesians parents are more open to changes but they are more emotionally unstable. These variations can influence their child-nurturing style.
\end{abstract}

KEYWORDS Big Five Theory, Generational Variation, Parenting Style

CITATION Susanto, N., \& Sulaiman, A. (2019). Kepribadian orangtua lintas generasi di indonesia: Tinjauan big five theory. Cognicia, 7(4), 539-551

Menurut Junginger (2008), dikarenakan lompatan ilmu dan teknologi dan arus globalisasi yang deras, kelompok generasi post-millenial atau yang lahir diatas tahun 1995 menjadi unik. Mereka memiliki beberapa karakter yang menonjol yaitu super kreatif, mencintai tantangan, tertarik untuk mencoba hal baru, tidak punya rasa takut akan masa depan, namun juga hyper sensitif dan cenderung merasa selalu ingin menang dan tidak ingin disalahkan.

Generasi post-millenial ini tidak sendiri. Menurut Oblinger and Oblinger (dalam Reeves \& Oh, 2008), terdapat tiga generasi lain yang lebih tua, yaitu Generasi Baby Boomers dengan tahun kelahiran 1947-1964, Generasi X dengan tahun kelahiran 1965-1980, Generasi Y (Millennials) dengan tahun kelahiran 1981-1994. Keempat generasi itu kini telah dewasa dan bersama-sama mereka menjadi bagian penting dalam mendorong perekonomian global. 
Pemahaman dasar mengenai pengelompokan generasi adalah adanya premis bahwa generasi adalah sekelompok individu yang dipengaruhi oleh kejadian-kejadian bersejarah atau fenomena budaya yang terjadi dan dialami pada fase kehidupan mereka. Perbedaan generasi tersebut membuat banyak peneliti yang menggunakan generasi sebagai bahan dari kajiannya. Termasuk Prinzie, Stams, Dekovic, Reijntjes, \& Belsky (2009) yang mencari hubungan antara kepribadian orangtua dengan pola pengasuhannya menggunakan teori Big Five Personality. Big Five Personality Theory adalah sebuah teori kepribadian yang dikembangkan oleh McCrae. Dalam dimensi Big Five Personality dijelaskan bahwa kepribadian individu terdiri dari lima sifat dasar. Kelima dimensi dasar tersebut digunakan untuk menggambarkan perbedaan dalam perilaku kognitif, afektif, dan sosialnya. Kelima dimensi dasar ini cenderung stabil sepanjang rentang kehidupan (Pervin \& John, 2005). Lima dimensi kepribadian dalam teori ini adalah Extraversion, Openness to Experience, Agreeableness, Conscientiousness, dan Emotional Stability.

Menurut McCrae dan Costa (dalam Iskandar, 2013) kelima kepribadian dasar tersebut mencakup: extraversion yang dicirikan dengan sikap positif seperti memiliki antusiasme yang tinggi, senang bergaul, mudah bersosialisasi, hidup berkelompok, dan tegas; agreeableness dicirikan dengan karakteristik yang mampu beradaptasi sosial yang baik dan mengindikasikan individu yang ramah, mampu berkerjasama, dan memiliki moralitas yang baik; Conscientiousness dicirikan cenderung mendengarkan kata hati, kerja keras, mengejar sedikit tujuan dalam satu cara yang terarah, bertanggungjawab, dan berorientasi pada prestasi; neuroticism dicirikan dengan kepemilikan emosi yang negatif seperti rasa khawatir, cemas, rasa tidak aman, dan labil; openness to experience yang mengacu pada bagaimana individu bersedia melakukan penyesuaian pada suatu ide atau situasi yang baru, imajinatif, kratif dan intelek. Menurut Prinzie, dkk. (2009) kelima kepribadian dasar tersebut mempunyai hubungan dengan pola pengasuhan yang terdiri dari tiga dimensi yaitu warm, behavioral control, dan autonomy support (Prinzie, dkk, 2009).

Menurut Baumrind (dalam Prinzie, 2009) menyatakan bahwa Warm (kehangatan) sering disebut responsif mengacu pada sejauh mana orang tua dengan sengaja menumbuhkan individualitas, pengaturan diri, mendukung, dan sering kali menyetujui kebutuhan dan permintaan khusus anak; behavioral control (kontrol perilaku) merujuk pada tuntutan orangtua atas kedewasaan anak, pengawasan, dan kedisiplinan; autonomy support (dukungan otonomi) mencangkup dorongan orangtua terhadap anak untuk secara aktif mengeksplorasi, menemukan, dan merumuskan pandangan dan tujuan dari anak.

Berdasar uraian diatas penulis mengambil judul penelitian "Kepribadian Orangtua Lintas Generasi di Indonesia: Tinjauan Big Five Theory". Tujuan 
penelitian ini adalah untuk memahami pola kepribadian orang tua Indonesia lintas generasi berdasarkan dimensi-dimensi kepribadian dalam Big Five Personality Theory. Diharapkan hasil penelitian ini dapat memberikan kita gambaran yang lebih lengkap dan terkini mengenai pola kepribadian orangtua dari berbagai generasi di Indonesia.

\section{METODE}

Metode penelitian yang digunakan dalam penelitian ini adalah metode deskriptif komparatif dengan pendekatan kuantitatif. Subjek penelitian ini berjumlah 80 subjek yang ambil secara acak. Subjek merupakan orang tua yang termasuk kedalam generasi baby boomers, $\mathrm{X}, \mathrm{Y}$ dan post-milenial yang bersedia untuk diambil data dan telah memiliki anak. Dengan jumlah masing-masing generasi yaitu 20 subjek.

\section{Usia}

Terdapat empat rentang usia yang menjadi target responden penelitian ini. Mereka antara lain generasi baby boomers, atau individual yang memiliki rentang usia 72-55 tahun, generasi $X$ dengan rentang usia 54-39 tahun, generasi $Y$ dengan rentang usia 38-24 tahun, dan generasi post-millennial dengan rentang usia 23-sekarang.

\section{Variabel Penelitian}

Variabel pertama dalam penelitian ini adalah kepribadian yang ditinjau dala 5 aspek berdasar teori Big Five Personality (i.e. Extraversion, Openness to Experience, Agreeableness, Conscientiousness, dan Emotional Stability). Variabel kedua dalam penelitian ini adalah generasi para subjek yang dirunut berdasar waktu kelahiran sebagaimana dijelaskan pada bagian usia.

\section{Instrumen}

Instrumen penelitian yang dipakai dalam menelitian ini adalah TIPI 25 yang sebelumnya telah diadaptasi oleh Akhtar \& Azwar (2018). Penelitian ini menggunakan penyebaran e-formulir dari TIPI 25 yang dibagikan secara acak di media sosial oleh tim peneliti.

\section{Teknik Analisis Data.}

Teknik analisis data yang digunakan dalam penelitian ini yaitu menggunakan One-Way ANOVA test, dikarenakan variabel peneltiain ini memiliki lebih dari 2 kelompok (4 kelompok generasi). Pengolahan data dibantu dengan perangkat lunak SPSS. 
HASIL

Tabel 1, Rata-rata skor Extraversion

\begin{tabular}{lc}
\hline Generasi & Extraversion \\
\hline Baby Boomers (1947-1964) & 16.04 \\
X (1965-1980) & 16.08 \\
Y (1981-1995) & 18.03 \\
Post Millennial (1995-sekarang) & 16.06 \\
\hline
\end{tabular}

Dari penelitian ini didapatkan hasil bahwa generasi baby boomers memiliki rata-rata Ekstraversion 16,04 dengan kategori sedang, generasi $\mathrm{X}$ memiliki rata-rata 16,08 dengan kategori sedang, generasi $Y$ memiliki rata-rata 18,03 dengan kategori tinggi, dan generasi post-millennial memiliki rata-rata 16.06 dengan kategori rendah.

Tabel 2, Rata-rata skor Agreeableness

\begin{tabular}{lc}
\hline Generasi & Agreeableness \\
\hline Baby Boomers (1947-1964) & 19.04 \\
X (1965-1980) & 19.02 \\
Y (1981-1995) & 20.09 \\
Post Millennial (1995-sekarang) & 19.07 \\
\hline
\end{tabular}

Dari penelitian ini didapatkan hasil bahwa generasi baby boomers memiliki rata-rata Agreeableness 19,04 dengan kategori tinggi, generasi $\mathrm{X}$ memiliki rata-rata 19,02 dengan kategori tinggi2, generasi Y memiliki rata-rata 20,09 dengan kategori tinggi, dan generasi post-millennial memiliki rata-rata 19,07 dengan kategori tinggi.

Tabel 3, Rata-rata Conscientiousness

\begin{tabular}{lc}
\hline Generasi & Conscientiousness \\
\hline Baby Boomers (1947-1964) & 20.08 \\
X (1965-1980) & 19.06 \\
Y (1981-1995) & 19.04 \\
Post Millennial (1995-sekarang) & 18.01 \\
\hline
\end{tabular}


Dari penelitian ini didapatkan hasil bahwa generasi baby boomers memiliki rata-rata Conscientiousness 20,08 dengan kategori tinggi, generasi $X$ memiliki rata-rata 19,06 dengan kategori tinggi, generasi $\mathrm{Y}$ memiliki rata-rata 19,04 dengan kategori tinggi, dan generasi post-millennial memiliki rata-rata 18.01 dengan kategori tinggi.

Tabel 4, Rata-rata Emotional Stability

\begin{tabular}{lc}
\hline Generasi & Emotional Stability \\
\hline Baby Boomers (1947-1964) & 17 \\
X (1965-1980) & 16.05 \\
Y (1981-1995) & 14.08 \\
Post Millennial (1995-sekarang) & 12.45 \\
\hline
\end{tabular}

Dari penelitian ini didapatkan hasil bahwa generasi baby boomers memiliki rata-rata Emotional Stability 17 dengan kategori sedang, generasi $X$ memiliki rata-rata 16,05 dengan kategori sedang, generasi $Y$ memiliki rata-rata 14,08 dengan kategori sedang, dan generasi post-millennial memiliki rata-rata 12,00 dengan kategori rendah.

Tabel 5, Rata-rata Openness to Experience

\begin{tabular}{lc}
\hline Generasi & Rata-rata Openness to Experience \\
\hline Baby Boomers (1947-1964) & 15.02 \\
X (1965-1980) & 17.01 \\
Y (1981-1995) & 18.01 \\
Post Millennial (1995-sekarang) & 19 \\
\hline
\end{tabular}

Dari penelitian ini didapatkan hasil bahwa generasi baby boomers memiliki rata-rata Openness to Experience 15,02 dengan kategori sedang, generasi $X$ memiliki rata-rata 17,01 dengan kategori sedang, generasi $Y$ memiliki rata-rata 18,01 dengan kategori tinggi, dan generasi post-millennial memiliki rata-rata 19 dengan kategori tinggi. 


\section{Analisis of Variance (ANOVA)}

Tabel 6, Tests of Normality

\begin{tabular}{lccc}
\hline & \multicolumn{3}{c}{ Shapiro-Wilk } \\
& Statistic & Df & Sig. \\
\hline Extraversion & .976 & 80 & .137 \\
Agreeableness & .971 & 80 & .064 \\
Conscientiousness & .971 & 80 & .063 \\
Emotional Stability & .974 & 80 & .106 \\
Openness to Experience & & & .088 \\
\hline
\end{tabular}

Salah satu syarat dilakukannya uji one-Way Anova adalah data berdistribusi normal sehingga diperlukan uji normalitas data pada sampel yang diambil pada penelitian ini. Sampel yang diambil dalam penelitian $t$ berjumlah 80 orang sampel yang dibagi menjadi 20 orang untuk masing masing kelompok generasi. uji normalitas yang digunakan adalah Shapiro-Wilk dibandingkan dengan Kolmogorov-Smirnov, karena sampe total < 50 (Dahlan, 2011). Berdasarkan hasil uji normalitas data dengan Shapiro-Wilk Test menunjukkan bahwa besarnya nilai signifikansi uji Shapiro-Wilk seluruh kelompok nilai BigFive Personality memiliki nilai melebihi $\mathrm{p}>0,05$ (nilai signifikansi). Berarti data yang diambil untuk kedua kelompok terdistribusi normal sehingga tidak terdapat perbedaan yang bermakna antara data yang akan diuji dengan data normal baku, sehingga uji parametrik dapat dilanjutkan.

Tabel 7, Test of Homogeneity of Variances

\begin{tabular}{llll}
\hline & df1 & df2 & Sig. \\
\hline Extraversion & 3 & 76 & .559 \\
Agreeableness & 3 & 76 & .400 \\
Conscientiousness & 3 & 76 & .862 \\
Emotional Stability & 3 & 76 & .059 \\
Openness to Experience & 3 & 76 & .226 \\
\hline
\end{tabular}

Uji homogenitas merupakan syarat kedua dalam melakukan test parametrik, tes One-Way ANOVA. Hasil diuji dikelompokkan berdasarkan jenis pemeriksaan. Pada tabel 1 menunjukan hasil tes homogenitas levene test 
pada seluruh hasil Nilai Big-Five Personality menunjukan signifikan diatas 0.005 ( $>0.05)$, sehingga menyimpulkan bahwa seluruh data adalah homogen.

Tabel 8, Perbandingan varian

ANOVA

\begin{tabular}{llrrr}
\hline & & Df & F & Sig. \\
\hline \multirow{4}{*}{ Extravertion } & Between Groups & 3 & 2.824 & .044 \\
& Within Groups & 76 & & \\
& Total & 79 & & \\
& Between Groups & 3 & 3.185 & .029 \\
Agreeableness & Within Groups & 76 & & \\
& Total & 79 & & .041 \\
& Between Groups & 3 & 2.891 & \\
Eonscientiousness & Within Groups & 76 & & \\
& Total & 79 & & \\
& Between Groups & 3 & 14.799 & \\
& Within Groups & 76 & & .000 \\
Openness to & Total & 79 & & \\
Experience & Between Groups & 3 & 14.035 & \\
& Within Groups & 76 & & \\
& Total & 515.388 & & \\
\hline
\end{tabular}

*Signifikan $P<0,05$

Dari tabel 8 diatas menunjukan bahwa hanya dua dimensi kepribadian yang memiliki perbedaan signifikan, yang ditunjukkan dengan nilai $\mathrm{p}<0.05$, diantara empat generasi orang tua di Indonesia. Dua dimensi tersebut adalah emotional stability dan openness to experience.

\section{PEMBAHASAN}

Berdasarkan analisis data, ditemukan terdapat perbedaan kepribadian orangtua antar lintas generasi (Baby Boomers, X, Y, dan Post Millenial) pada sebagian aspek kepribadian (i.e. Openness to experience, emotional stability) dan tidak adanya perbedaan yang signifikan pada tiga aspek kepribadian lain. Perbedaan tersebut terlihat dari hasil skoring yang dilakukan menggunakan Skala TIPI 25 dengan menggunakan dimensi Big Five Pesonality yang terdiri atas Extraversion, Openness to Experience, Agreeableness, Conscientiousness, dan Emotional Stability.

Dilihat dari dimensi kepribadian Extraversion, generasi Y memilki jumlah skoring yang lebih tinggi dibandingkan dengan tiga generasi lainnya. Hal ini menandakan bahwa orangtua yang berada pada generasi $\mathrm{Y}$ cenderung 
memiliki kepribadian yang terbuka, senang bergaul, mudah bersosialisasi, hidup berkelompok, dan tegas. Hal ini sesuai dengan penelitian yang dilakukan oleh Andiyasari, Si, Pitaloka, and Si (2010) yang menyatakan bahwa Generasi Y menggambarkan seseorang yang memiliki keterampilan manajemen, menyenangkan (mudah bergaul), dapat didekati, mau mengerti, perhatian, peduli, memberikan dukungan, berpikiran terbuka, dan menghormati nilainilai. Selain itu, menurut Lancaster and Stillman (2003) dalam Putra (2017) menyatakan bahwa generasi Y juga memiliki Memiliki rasa optimis yang tinggi, fokus pada prestasi, percaya diri, percaya pada nilai-nilai moral dan sosial. Hal tersebut juga sesuai dengan karakteristik kepribadian Extraversion yang memiliki tingkat motivasi yang tinggi. Sebaliknya, Individu yang Introversion (Kebalikan dari Extraversion) adalah mereka yang pemalu, suka menyendiri (Rapika \& Sari, 2017).

Agreeableness yaitu karakteristik kepribadian yang menunjukan sikap mudah percaya, bersepakat, berkerjasama, dan memiliki moralitas yang baik. Dari data diatas didapatkan hasil bahwa generasi yang mendapatkan skor tertinggi yaitu generasi Y. Hal ini menunjukan orangtua yang merupakan generasi Y memilki karakteristik kepribadian Agreeableness yang baik. Menurut Kusmayati (2018) menyatakan bahwa generasi Y memilki perspektif yang optimis, kooperatif (berkejasama), berkolaborasi, percaya, dan idealis. Sedangkan menurut menurut Lancaster and Stillman (2003) dalam Putra (2017) menyatakan bahwa generasi $\mathrm{Y}$ dalam berkerja memiliki karakteristik yaitu percaya pada nilai-nilai moral dan sosial, menghargai adanya keragaman, dan percaya diri. Hal tersebut sesuai dengan karakteristik dari kepribadian Agreeableness yang cenderung memilki Moraity (moralitas), Trust (kepercayaan), Altruism (pengorbankan), Modesty (kesopanan), Sympathy (simpati), dan Cooperation (kerjasama) (Rapika \& Sari, 2017).

Karakteristik sebaliknya dari Agreeableness adalah mereka yang tidak mudah berserpakat dengan individu lain. Menurut Robbins dalam Mastuti (2005) menyatakan bahwa orang yang menilai rendah kemampuannya untuk bersepakat (Agreeableness) akan memusatkan peerhatian lebih pada kebutuhan mereka sendiri, dari pada kebutuhan oranglain. Dari data diatas didapatkan bawah generasi Baby Boomers dan $X$ memiliki nilai yang sama dibawah generasi Y. Menurut Widagdo (2016) generasi Baby Boomers percaya bahwa aturan-aturan yang ada dimaksudkan untuk ditantang dan diubah. Mereka cenderung menjadi mandiri dan individualistis dikarenakan faktor lingkungan mereka dibesarkan yang sulit. Sedangkan menurut Kusmayati (2018) generasi X memiliki karakteristik individualistis. Maka dari itu, hal tersebut sesuai dengan data yang kami dapatkan bahwa generasi Baby Boomers dan $X$ memiliki emiliki jumlah skor yang paling rendah diantara generasi lainnya. Yang berarti bahwa generasi ini memiliki kepribadian terbaliknya dari Agreeableness yaitu 
tidak mudah berserpakat dengan individu lain karena mereka cenderung individualistis.

Dilihat dari dimensi kepribadian Conscientiousness. Generasi yang memiliki skor Conscientiousness tertinggi yaitu generasi Baby Boomers. Hal ini berarti bawah generasi Baby Boomers memiliki karakteristik berhati-hati, teratur, teliti, dan berkerja keras dalam bertindak. Menurut (Mastuti, 2005) seseorang yang mempunyai skor Conscientiousness tinggi cenderung mendengarkan kata hati, kerja keras, mengejar sedikit tujuan dalam satu cara yang terarah, bertanggungjawab, dan berorientasi pada prestasi. Generasi Baby Boomers percaya bahwa kerja keras dan pengorbanan adalah sesuatu yang harus dibayar dalam upaya untuk mencapai kesuksesan di masa yang akan mendatang. Kehidupan Baby Boomers yang keras dan juga dituntut kemandirian membentuk mereka menjadi orang-orang yang kuat. Mereka menjadi pekerja keras, memiliki loyalitas yang tinggi, serta obsesi yang besar untuk mencapai impian mereka (Widagdo, 2016)

Sedangkan seseorang yang memiliki skor rendah pada Conscientiousness, maka akan cenderung menjadi lebih kacau pikannya dikarenakan banyak mengejar tujuan dan lebih hedonistic. Skor Conscientiousness terendah dimiliki oleh generasi Post Millenial, hal ini berarti bawah Post Millennial memiliki karakteristik cenderung tidak hati-hati, tidak teliti, malas, tidak teratu, dan memilki perilaku hedonism (Sudarsih, 2011). Menurut Pratama (2012) generasi Post Millennial mempunyai karakteristik yang berbeda dari generasi sebelumnya yaitu konsumerisme luar biasa tinggi dan cenderung habiskan uang untuk saat ini, bukan untuk jangka panjang. Arus globalisasi juga membuat masyarakat saat ini cenderung menginginkan hal yang instan karena tersedianya teknologi-teknologi yang memudahkan segala aktifitas, sehingga mereka cenderung memilki sikap pemalas, mudah menyerah, dan tidak ingin berusaha keras. Dengan demikian generasi Post Millennial cenderung memiliki kepribadian Conscientiousness yang rendah seiriring dengan zaman yang semakin berkembang (Yanti, Janah, \& Bustamam, 2016).

Neuroticism yaitu kepribadian yang cenderung berkaitan dengan trait negatif. Orang yang memiliki skor tinggi dalam dimensi Neuroticism akan cenderung memiliki rasa gugup, mudah cemas, mudah depresi, dan sering berubah pikiran (Rapika \& Sari, 2017). Karakteristik positif dari dimensi ini disebut dengan Emotional Stability (Stabilitas Emosional), Individu dengan Emosional yang stabil cenderung tenang saat menghadapi masalah, percaya diri, memiliki pendirian yang teguh. Berdasarkan data yang diperoleh, Generasi Post Millennial memiliki skor Emotional Stability yang rendah dan skor tertinggi diperoleh oleh Generasi Baby Boomers. Hal ini berarti seiring dengan berkembangan zaman dan perubahan generasi kestabilan emosi manusia mengalami penurunan, membuat manusia menjadi cenderung memiliki 
kepribadian Neuroticism. Hal ini terbukti berdasarkan data yang diperoleh oleh Kementrian Kesehatan Republik Indonesia, bahwa prevalensi gangguan mental emosional di Indonesia meningkat dari tahun ketahun dengan gejala-gejala depresi dan kecemasan untuk usia 15 tahun ke atas. Pada tahun 2016 mencapai sekitar 14 juta orang atau 6\% dari jumlah penduduk Indonesia. Sedangkan Generasi baby boomers mempunyai karakter yang berorientasi pada kenyamanan dan cenderung tenang saat menghadapi masalah. Sehingga membuat mereka memiliki Stabilitas Emosional yang baik.

Openness to Experience atau biasa disebut dengan intellect, merupakan dimensi kepribadian yang berkarakteristik mudah terpesona oleh hal baru dan inovasi. Kepribadian ini cenderung akan menjadi seseorang yang imajinatif, kratif dan intelek. Dari data diatas didapatkan hasil bahwa skor dimensi Openness to Experience tertinggi diperoleh oleh Generasi Post Millennial. Hal ini berarti bawah generasi saat ini memiliki intellect yang cukup bagus dibandingkan dengan generasi sebelum-sebelumnya. Menurut Merari and Suyasa (2016) Generasi Post Millennial cenderung baik dalam multitasking ataupun task switch meskipun perkembangan otak generasi ini juga memiliki efek buruk berupa AADD (Acquired Attention Deficit Disorder) yaitu perubahan pada otak karena pemakaian teknologi yang begitu besar oleh gen $\mathrm{Z}$ yang berdampak kesulitan untuk fokus dan menganalisa informasi yang beragam, hal ini sangat dipengaruhi kebiasaan otak mendapatkan informasi yang pendek dan cepat melalui media social. Selain itu juga Generasi Post Millennial cenderung lebih bisa banyak mengakses informasi baik ilmu pengetahuan atau ilmu lainnya, sehingga membuat generasi Post Millennial lebih imajinatif, kreatif, dan aktif. Sedangkan generasi Baby Boomers pada saat itu belum mampu menerima informasi yang cukup banyak dikarenakan keterbatasan media informasi yang belum berkembang. Dari data yang didapatkan dari keempat generasi, generasi Baby Boomers memilki skor yang rendah dalam dimensi intellect. Dan data diatas juga didapatkan hasil bahwa semakin berkembangnya zaman dan perubahan dari generasi ke generasi manusia cenderung memiliki kepribadian intellect yang baik.

Menurut Prinzie dkk. (2009) kelima kepribadian dasar diatas mempunyai hubungan dengan pola pengasuhan anak yang terdiri dari tiga dimensi yaitu warm, behavioral control, dan autonomy support. Dalam penelitian yang dilakukan oleh Prinzie, dkk. (2009) bahwa tingkat Extraversion, Openness to Experience, Agreeableness, Conscientiousness yang lebih tinggi dari pada Neuroticism maka memiliki pola pengasuhan warm dan behavioral control. Sedangkan jika tingkat Agreeableness yang lebih tinggi dan tingkat Neuroticism yang lebih rendah, maka berhubungan dengan pola pengasuhan autonomy support, atau mendorong kemandirian anak. Generasi baby boomers dan Generasi $X$ memiliki nilai Agreeableness dan Conscientiousness dengan kategori tinggi. 
Menurut Michalik (2005) dalam penelitiaannya menemukan bahwa, orangtua yang memiliki nilai Agreeableness dan Conscientiousness yang tinggi maka akan memberikan pola pengasuhan yang hangat. Hal ini berarti bahwa orangtua pada generasi baby boomers dan $X$ memiliki pola pengasuhan yang cenderung berhati lembut dan ramah pada anak, penuh toleransi, membuat tuntutan yang rasional, dan tetap menghargai kedisiplinan anak.

Sedangkan Generasi $Y$ memiliki nilai Extraversion, Agreeableness, Conscientiousness dan Openness to Experience dengan kategori tinggi. Menurut Verhoeven (2007) dalam penelitiannya menemukan bahwa, orangtua yang memiliki nilai Extraversion, Agreeableness, Conscientiousness, Neuroticism, dan Openness to Experience yang tinggi maka akan memberikan pola asuh yang hangat, mengontrol perilaku, dan dukungan otonomi. Dalam hal ini generasi $\mathrm{Y}$ cenderung memiliki nilai tinggi dalam 4 aspek kepribadian Big Five Personality, kecuali Neuroticism. Hal ini berarti bahwa orangtua pada generasi Y memiliki pola pengasuhan yang cenderung berhati lembut, penuh kasih sayang dan ramah pada anak, terkadang terlibat dalam aktifitas anak, menghargai kedisiplinan anak, memberikan kontrol terhadap perilaku anak, membuat tuntutan yang rasional, dan walaupun terkadang suka mencemasi anak dengan menerapkan self-control secara kaku.

Generasi post-millennial memiliki nilai Agreeableness, Conscientiousness dan Openness to Experience dengan kategori tinggi. Sedangkan Emotional Stability yang dimiliki oleh generasi ini cenderung rendah. Menurut Neitzel \& Stright (2004) dalam penelitiannya menemukan bahwa, orangtua yang memiliki nilai Openness to Experience, Agreeableness, dan Conscientiousness yang tinggi akan memberikan pola asuh yang hangat dan dukungan otonomi. Hal ini berarti bahwa orangtua pada generasi post-millennial, cenderung responsif terhadap anak dengan menumbuhkan sikap individualitas, sering memberi dukungan, dan mengajarkan anak-anak untuk secara aktif mengeksplorasi, menemukan, dan merumuskan pandangan dan tujuan mereka sendiri.

\section{SIMPULAN \& IMPLIKASI}

Berdasarkan hasil dari penelitian ini dapat ditarik kesimpulan bahwa pola karakter kepribadian orangtua Indonesia dari empat generasi memiliki perbedaan yang signifikan dalam dua dimensi yaitu openness to experience dan emotional stability. Orangtua Indonesia yang berada pada generasi yang lebih muda (milenial dan post-milenial) cenderung memiliki keterbukaan yang lebih tinggi atas pengalaman dan perubahan namun stabilitas emosi yang lebih rendah ketimbang generasi yang lebih tua.

Hal ini dapat berimplikasi pada pengasuhan orangtua dari generasi ke generasi yang mengalami perubahan. Perbedaan kecenderungan kepribadian orangtua setiap generasinya memiliki pengaruh dalam pola pengasuhan yang 
diberikan kepada anak. Generasi baby boomers dan Generasi X cenderung memberikan pola pengasuhan yang hangat. Sementara, generasi Y cenderung memberikan pola pengasuhan yang hangat, mengontrol perilaku, dan dukungan otonomi. Sedangkan Generasi post-millennial cenderung memberikan pola pengasuhan yang hangat dan dukungan otonomi.

\section{REFERENSI}

Akhtar, H., \& Azwar, S. Indonesian Adaptation and Psychometric Properties Evaluation of the Big Five Personality Inventory: IPIP-BFM-50. Jurnal Psikologi, 46(1), 32-44.

Andiyasari, A., Si, M., Pitaloka, A., \& Si, M. (2010). Persepsi kepemimpinan otentik dan work engagement pada generasi $x \& y$ di indonesia. Jurnal Universitas Paramadina, 7(1), 371-388.

Dahlan, M. S. (2011). Statistik untuk kedokteran dan kesehatan: Penerbit Salemba.

Habiebi, A. N. (2019). Prevalensi dan korelasi bullying diantara remaja di Indonesia : analisis data sekunder survei kesehatan berbasis sekolah. Universitas Airlangga,

Iskandar, L. M. (2013). Penyesalan pasca pembelian ditinjau dari Big Five Personality. Jurnal Psikologi, 40(1), 81-91.

Junginger, C. (2008). Who is training whom: the effect of the millennial generation. FBI L. Enforcement Bull., 77, 19.

Kusmayati, N. K. (2018). Analisis prespektif nilai individu, hubungan kerja dan sistem kerja karyawan generasi Y dan generasi X di Indonesia. Media Mahardhika, 16(3), 371-391.

Lancaster, L. C., \& Stillman, D. (2003). When generations collide: Who they are, why they clash, how to solve the generational puzzle at work: HarperBusiness New York, NY.

Mastuti, E. (2005). Analisis faktor alat ukur kepribadian big five (adaptasi dari IPIP) pada mahasiswa suku jawa. Insan, 7(3), 264-276.

Merari, L., \& Suyasa, I. K. (2016). Generasi Y, generasi Z, dan bonus demografi indonesia 2025. Jakarta Barat: Magister Manajemen, Fakultas Ekonomi, Universitas Trisakti.

Michalik, N. M. (2005). Determinants of adolescent prosocial behavior: Parental personality and socialization (Doctoral dissertation, Arizona State University, 2005). Dissertation Abstracts International, 66, 490.

Neitzel, C., \& Stright, A. D. (2004). Parenting behaviors during child problem solving: The role of child temperament, mother education and personality, and the problem-solving context. International Journal of Behavioral Development, 28, 166-179.

Pratama, H. C. (2012). Cyber smart parenting: kiat sukses menghadapi dan mengasuh generasi digital: Visi Press.

Prinzie, P., Stams, G. J. J., Deković, M., Reijntjes, A. H., \& Belsky, J. (2009). The relations between parents' Big Five Personality factors and parenting: A meta-analytic review. Journal of personality and social psychology, 97(2), 351.

Putra, Y. S. (2017). Theoritical review: Teori perbedaan generasi. Jurnal Ilmiah Among Makarti, $9(18)$.

Rapika, S., \& Sari, A. P. (2017). Pengaruh kepribadian dan kemampuan intelektual terhadap kompetensi guru di SMKN 3 Kota Bengkulu. Managament Insight: Jurnal Ilmiah Manajemen, 12(2), 64-76.

Reeves, T. C., \& Oh, E. (2008). Generational differences. Handbook of research on educational communications and technology, 3, 295-303.

Sudarsih, S. (2011). Konsep hedonisme epikuros dan situasi Indonesia masa kini. Humanika, 14(1).

Widagdo, P. P. (2016). Pengaruh kesesuaian teknologi terhadap tugas terhadap kinerja individu pada generasi baby boomers (1945-1964) dalam menggunakan teknologi informasi (Studi 
Kasus: Universitas Mulawarman). Informatika Mulawarman: Jurnal Ilmiah Ilmu Komputer, 11(2), 54-60.

Yanti, F., Janah, N., \& Bustamam, N. (2016). Dinamika kecenderungan gaya hidup hedonis dan perilaku seks bebas pada remaja putri. JIMBK: Jurnal Ilmiah Mahasiswa Bimbingan \& Konseling, 1(1).

Verhoeven, M., Junger, M., Van Aken, C., Dekovic', M., \& Van Aken, M. A. G. (2007). Parenting during toddlerhood: Contributions of parental, contextual, and child characteristics. Journal of Family Issues, 28, 1663-1691 